\title{
Straight Bevel Gears Manufacturing Analysis by Conventional Powder Metallurgy Process
}

\author{
Clayton A. de Oliveira-Motta ${ }^{1}$, José de Souza ${ }^{2}$, Ana Paula S. de Matos Dias ${ }^{3}$, \\ Arão de Matos Dias ${ }^{4}$, Eduardo Henrique de Souza Cardoso ${ }^{5}$ Lirio Schaeffer ${ }^{6}$ \\ ${ }^{1,6}$ (Universidade Federal do Rio Grande do Sul - UFRGS - LdTM - Porto Alegre/RS - Brasil) \\ ${ }_{2}^{2}$ (Fundação Liberato - Diretoria de Produção e Pesquisa Industrial - DPPI - Novo Hamburgo/RS - Brasil) \\ ${ }^{3}($ LdTM - Aron Metal Ltda - Canoas/RS - Brasil) \\ ${ }^{4}$ (Aron Metal Ltda - Canoas/RS - Brasil) \\ ${ }^{5}$ (Escola Técnica Estadual Monteiro Lobato - CIMOL - Curso de Mecânica - Taquara/RS - Brasil)
}

\begin{abstract}
In this paper it was proposed the manufacture of a component of the agricultural sector machine with conventional Powder Metallurgy (PM) techniques. The proposed process was developed with a Straight Bevel Gears, which is currently manufactured by other manufacturing processes, such as machining and forming. The gearwheel is part of a gearbox that replaces speed reduction. The component developed by powder metallurgy is low-carbon iron, in relation to Ni (nickel), Cu (copper) Mo (molybdenum) in large quantities. It was sought to verify the dimensional behavior with Statistical Process Control (SPC) techniques and also its properties through the analysis of the densities obtained in the gears during the powder metallurgy process. It was found that the parts fulfilled the requirements for coupling operation, such as those processed by other processing methods. The mechanical properties checked fully met the minimum requirements for these components. The chemical composition generated for the sprocket also pleased satisfied for this use.
\end{abstract}

Keywords: Conventional Powder Metallurgy, Straight Bevel Gears, Statistical Process Control.

\section{Introduction}

The Powder Metallurgy Process (PMP) consists of obtaining Metallic Powder and its transformation through important steps such as sintering compaction and treatment at temperatures below the melting point of the base metal [1-2]. This process, characteristic of powder metallurgy, results in high precision products and offers mechanical and desired characteristics to the products [3-4].

The desired chemical composition for the final product is controllable in Powder Metallurgy (M.P.). Different metal powders can be mixed in the specified proportions. The desired chemical composition can be obtained from powders of alloys with metallic and non-metallic powders. [5]. It is very difficult to obtain a solid, homogeneous material by the sintering of elemental metallic powders and it is very difficult to occur a diffusibility between alloying elements [6].

Powder Metallurgy has as main advantages the use of simple ovens and with low energy consumption [7]. This is because it requires lower sintering temperatures when compared to other processes using larger furnaces. The final product may not require dimensional adjustments since it has excellent dimensional tolerance. Associated with tolerances to M.P., it can, in many cases, dispense with surface finishing operations. Another relevant and favorable factor to M.P., is related to the process generate pre-defined formats, making the construction of high complexity parts less costly and the process more competitive [8-9].

Statistical Process Control (SPC) is a widely used approach to process improvement. With this tool it is possible to prevent defects, increase productivity, and adjust the process [10]. Statistical Process Control is a tool that can guarantee the quality of the process and the product and thus better management of the Quality Management System (QMS) of a company or corporation [11].

The SPC consists of methods for understanding, monitoring and improving process performance over time. This process was developed by Walter Shewhart during the 1920s. It is now perceived that the SPC is not only a collection of techniques but a way of thinking about quality improvement. Many companies consider Statistical Process Control as an important tool in Total Quality Management (TQM) and also in their Quality Management System (QMS) [12]. 


\section{Method and Materials}

The objective of the paper is the development of a sintered Straight Bevel Gears used in agricultural planting machine. The compound used for mass balance was $\mathrm{Fe}-2 \mathrm{Cu}-0.4$ Graphite, where $\mathrm{Fe}$ (Iron) processed by atomization and $\mathrm{Cu}$ (Copper), processed electrolytically.

The samples were compacted into a set of tools composed of: die, superior punch, inferior punch and a guide for calibrates the inner diameter of the gear. The manufacture of a Straight Bevel Gears using the conventional Powder Metallurgy Process has been a challenge. The difficulty in manufacturing this type of product is even greater when produced in simple stage presses, where only one movement occurs at the superior punch and one movement at the inferior punch. A Straight Bevel Gears processed by the conventional Powder Metallurgy Process is presented (Fig. 1).

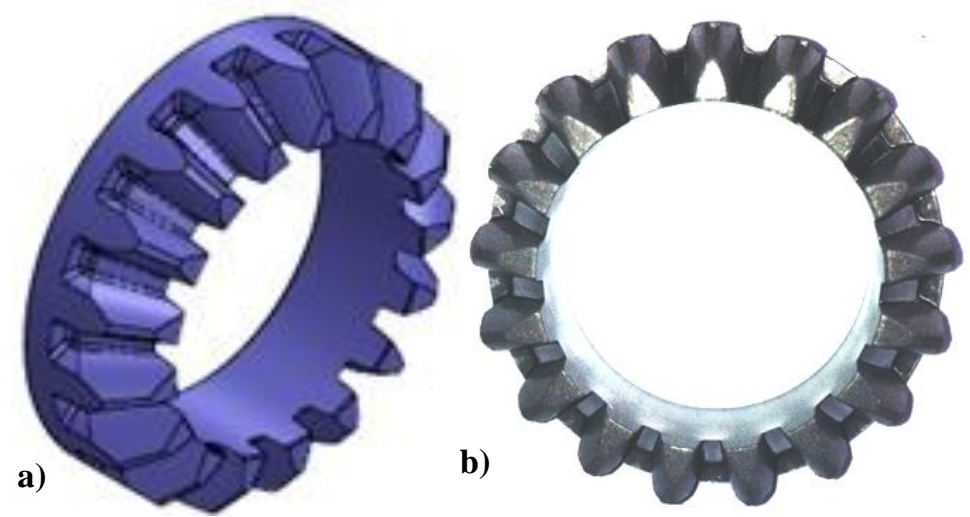

Figure 1. Straight Bevel Gears manufacturing. a) Design. b) Manufactured.

The variables observed for this research were the density, due to its punctual distribution in each sample and the variation in the gear teeth. Measurements of tooth densities were evaluated separately in this study. The purpose of this method was to identify and validate the average density required for this product (6.4 to $6.6 \mathrm{~g} / \mathrm{cm}^{3}$ ). Measurements were also made at the tooth heights.

The punch that compacts the teeth consists of a single part (Fig. 2). The teeth are compacted in a single level. This can result in differences in density between the work teeth and the base of the gear, because the filling height is not proportional.

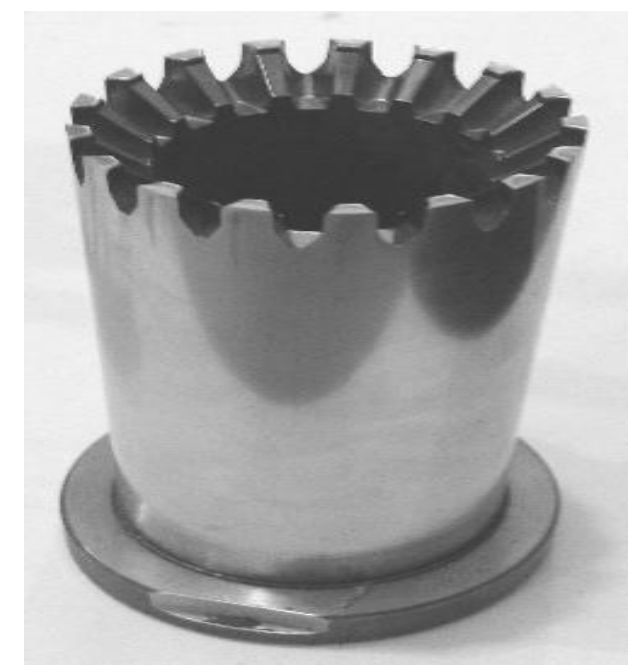

Figure 2. Superior Punch Die.

It is characteristic of the M.P. techniques that the filling height for a density around $6.6 \mathrm{~g} / \mathrm{cm}^{3}$ should be 2 for 1, i.e., the loose powder in the die cavity, should be twice the height of the compacted part. When this does not occur, variations in the density of the compacted can occur, promoting differences of mechanical properties in different regions. 


\subsection{Compaction and Sintering of Samples}

The samples were compacted to a density of approximately $6.6 \mathrm{~g} / \mathrm{cm}^{3}$, this density is considered a mean density for sintered parts. The process took place in a hydraulic press with single-acting pressing up to 200 Tons of force. The sintering was done in a continuous furnace, with atmosphere controlled by nitrogen and hydrogen with percentages of $80 \%$ and $20 \%$ respectively. The sintering temperatures inside the furnace obeyed the following conditions:

- $\quad 550^{\circ} \mathrm{C}-30$ minutes (first zone);

- $\quad 900^{\circ} \mathrm{C}-30$ minutes (second zone);

- $\quad 1100^{\circ} \mathrm{C}-30$ minutes (third zone).

The third zone is the sintering region. Cooling was dependent on the speed of the conveyor and measured 3 (three) hours to room temperature.

\section{Analysis of Results}

\subsection{Analysis of Tooth Density with the use of Statistical Process Control}

Twenty-four samples from three different gears were analyzed after the sintering process. These samples taken from the cogs served to analyze the behavior of the density variation in each tooth. The measurements were made using the Archimedes Principle. The results of the analyzes are shown in Table 1. The mass, volume and density variation of each part tested is shown (Fig. 3).

Table 1. Density values tested in each Sample.

\begin{tabular}{|c|c|c|c|}
\hline Samples & Mass $(\mathrm{g})$ & Volume $\left(\mathrm{cm}^{3}\right)$ & Density $\left(\mathrm{g} / \mathrm{cm}^{3}\right)$ \\
\hline 1 & 5.37 & 0.83 & 6.46 \\
\hline 2 & 5.47 & 0.87 & 6.28 \\
\hline 3 & 4.36 & 0.68 & 6.41 \\
\hline 4 & 4.49 & 0.67 & 6.70 \\
\hline 5 & 4.38 & 0.69 & 6.34 \\
\hline 6 & 5.45 & 0.88 & 6.19 \\
\hline 7 & 4.41 & 0.68 & 6.48 \\
\hline 8 & 6.20 & 0.99 & 6.26 \\
\hline 9 & 5.23 & 0.80 & 6.53 \\
\hline 10 & 6.46 & 1.06 & 6.09 \\
\hline 11 & 5.54 & 0.91 & 6.08 \\
\hline 12 & 5.33 & 0.84 & 6.34 \\
\hline 13 & 5.30 & 0.80 & 6.62 \\
\hline 14 & 4.65 & 0.73 & 6.36 \\
\hline 15 & 4.77 & 0.72 & 6.62 \\
\hline 16 & 4.77 & 0.74 & 6.44 \\
\hline 17 & 4.95 & 0.77 & 6.42 \\
\hline 18 & 4.51 & 0.71 & 6.35 \\
\hline 19 & 4.78 & 0.74 & 6.45 \\
\hline 20 & 4.96 & 0.77 & 6.44 \\
\hline 21 & 3.56 & 0.58 & 6.17 \\
\hline 22 & 5.06 & 0.76 & 6.65 \\
\hline 23 & 5.86 & 0.89 & 6.58 \\
\hline 24 & 5.24 & 0.79 & 6.63 \\
\hline & & & \\
\hline
\end{tabular}

In order to determine the Statistical Process Control parameters, the following equations were used:

General Mean of the Samples:

$\mathrm{X}=(\Sigma \mathrm{X}) / \mathrm{n}=\left(\mathrm{X}_{1}+\mathrm{X}_{2}+\ldots+\mathrm{X}_{\mathrm{n}}\right) / \mathrm{n}$

$\mathrm{X}=6.41$

Average Range of Samples:

$\mathrm{R}=\mathrm{X}_{\max }-\mathrm{X}_{\min }$

$\mathrm{R}=0.62$

Mean Standard Deviation of the Samples:

$\mathrm{S}^{2}=1 /(\mathrm{n}-1) . \Sigma(\mathrm{Xi}-\mathrm{X})^{2}$

$\mathrm{S}=0.17507711$

Upper Limit of Control (UCL): $\mu+3 \sigma=6.93$

Lower Limit of Control (LCL): $\mu-3 \sigma=5.88$ 


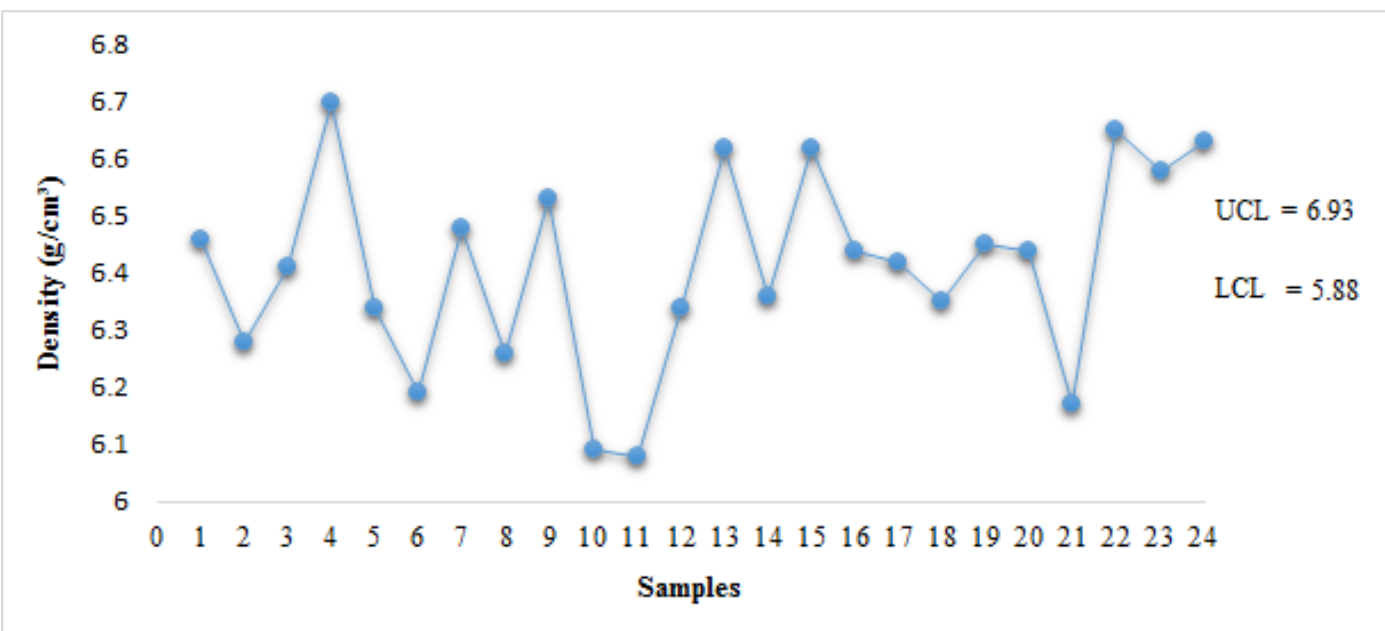

Figure 3. Verification of the Density variation of each Sample.

3.2 Analysis of the Topland and the Bottomland variation in relation to the Base of the Gear

In the 2D projection the gear and the variables $h_{t}$ (Topland height from the base) and another one titled as $h_{b}$ (Bottomland height from the base) (Fig.4).

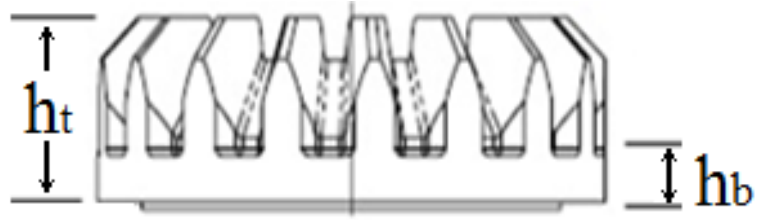

Figure 4. Verification of the Density variation of each Sample.

The $h_{t}$ measurements were performed on 10 (ten) different sintered samples, and each part was submitted to 4 (four) checks. The analyzes performed are represented in the Table 2 .

Table 2. Measures of height of the tooth, $\mathrm{h}_{\mathrm{t}}(\mathrm{mm})$.

\begin{tabular}{|c|c|c|c|c|}
\hline Samples & Measure 1 & Measure 2 & Measure 3 & Measure 4 \\
\hline 1 & 13.38 & 13.41 & 13.39 & 13.37 \\
\hline 2 & 13.36 & 13.36 & 13.40 & 13.38 \\
\hline 3 & 13.42 & 13.43 & 13.41 & 13.40 \\
\hline 4 & 13.47 & 13.47 & 13.48 & 13.49 \\
\hline 5 & 13.35 & 13.37 & 13.35 & 13.38 \\
\hline 6 & 13.38 & 13.39 & 13.39 & 13.41 \\
\hline 7 & 13.41 & 13.42 & 13.38 & 13.40 \\
\hline 8 & 13.39 & 13.36 & 13.37 & 13.40 \\
\hline 9 & 13.37 & 13.41 & 13.40 & 13.39 \\
\hline 10 & 13.45 & 13.43 & 13.47 & 13.46 \\
\hline
\end{tabular}

Immediately after performing the analyzes performed and presented in Table 2 for the variable $h_{t}$, analyzes were made at the bottom of the tooth in relation to the base of the piece $h_{b}$.

Average of the samples: $X=53.61$.

Mean Range of Samples: $R=0.14$.

Mean Standard Deviation of the Samples:

$\mathrm{S}^{2}=1 /(\mathrm{n}-1) . \Sigma(\mathrm{Xi}-\mathrm{X})^{2}$

$\mathrm{S}=0.03712$

Upper Control Limit (UCL): $\mu+3 \sigma$

Measure 1: 13.5073;

Measure 2: 13.50607;

Measure 3: 13.52345;

Measure 4: 13.51384

Lower Limit of Control (LCL): $\mu-3 \sigma$

Measure 1: 13.2727;

Measure 2: 13.29393; 
Measure 3: 13.27655;

Measure 4: 13.28616.

For a better evaluation and analysis, the data of (Table 2) were plotted as a graph (Fig. 5).

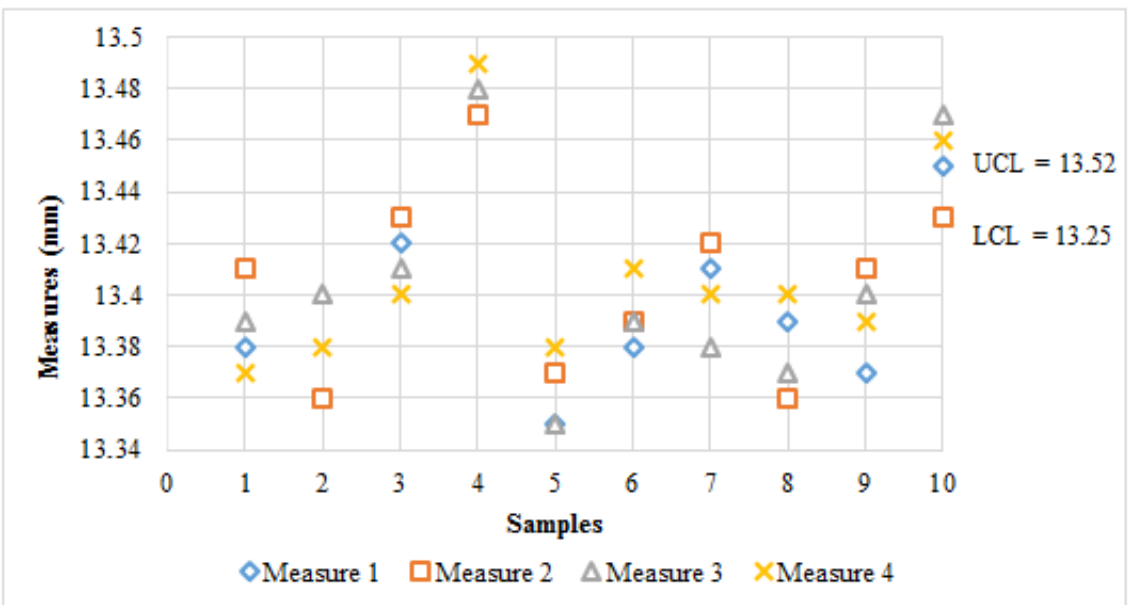

Figure 5. Variation $h_{t}$ (Gear tooth height relative to the workpiece base) (mm) for each Sample and control limits, based on the Standard Deviation.

As was the case for the tooth height variable in relation to the gear base, the $\mathrm{h}_{\mathrm{b}}$ measurements were performed on 10 (ten) different sintered parts. Again, each piece was subjected to 4 (four) checks. The analyzes performed are shown in Table 3. The $\mathrm{h}_{\mathrm{b}}$ measurements were taken using an Measuring System.

Table 3. Measures of height of the Gear Tooth, $h_{b}$.

\begin{tabular}{|c|c|c|c|c|}
\hline Samples & Measure 1 & Measure 2 & Measure 3 & Measure 4 \\
\hline 1 & 3.54 & 3.51 & 3.54 & 3.50 \\
\hline 2 & 3.53 & 3.52 & 3.45 & 3.50 \\
\hline 3 & 3.48 & 3.63 & 3.49 & 3.49 \\
\hline 4 & 3.58 & 3.57 & 3.58 & 3.60 \\
\hline 5 & 3.44 & 3.46 & 3.45 & 3.46 \\
\hline 6 & 3.46 & 3.46 & 3.51 & 3.49 \\
\hline 7 & 3.51 & 3.49 & 3.48 & 3.47 \\
\hline 8 & 3.52 & 3.48 & 3.54 & 3.52 \\
\hline 9 & 3.52 & 3.48 & 3.47 & 3.47 \\
\hline 10 & 3.56 & 3.52 & 3.56 & 3.56 \\
\hline
\end{tabular}

For a better evaluation and analysis of the data in (Table 3) the $h_{b}$ analysis was plotted as a graph, as can be seen in (Fig. 6).

General average of Samples: $X=14.029$

Mean Range of Samples: $\mathrm{R}=0.14$

Mean Standard Deviation of the Samples:

$\mathrm{S}^{2}=1 /(\mathrm{n}-1) . \Sigma(\mathrm{Xi}-\mathrm{X})^{2}$

$\mathrm{S}=0.040824$

Upper Control Limit (UCL) $\mu+3 \sigma$ :

Measure 1: 3.644537;

Measure 2: 3.60573;

Measure 3: 3.6456;

Measure 4: 3,637,301.

Lower Control Limit (LCL) $\mu-3 \sigma$ :

Measure 1: 3.383463;

Measure 2: 3.399827;

Measure 3: 3.3684;

Measure 4: 3.374699 . 


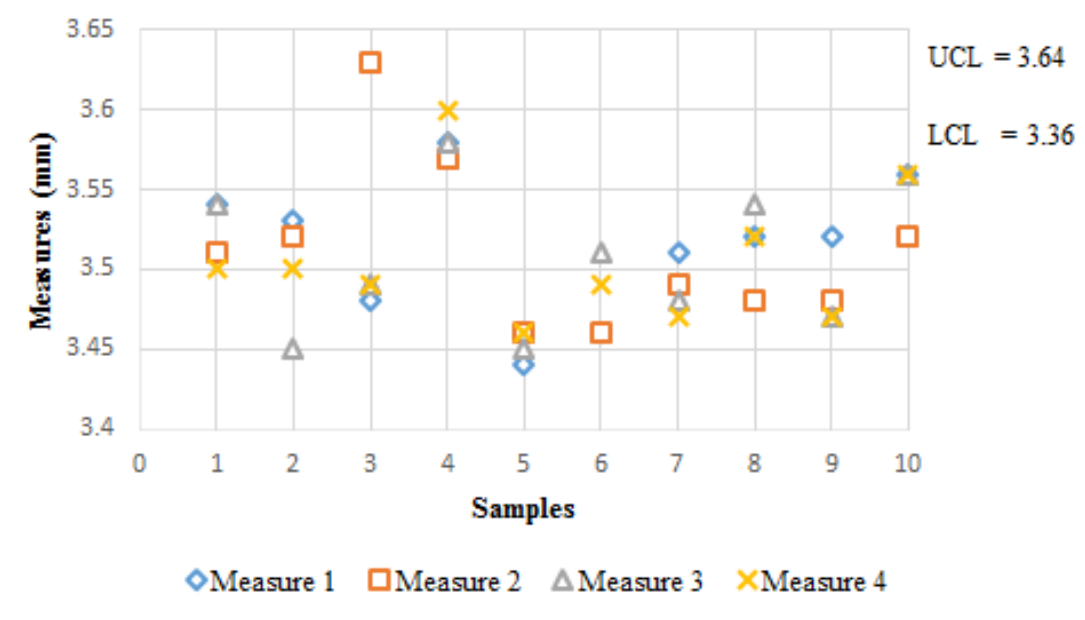

Figure 6. Variation $\mathrm{h}_{\mathrm{f}}($ Gear Tooth Height) for each sample and control limits, based on Standard Deviation.

\section{Conclusion}

It was observed that the parts fulfilled the necessary requirements for the operation of the gear unit without interference. Regarding the mechanical properties, there was no problem, because the material used was designed to withstand at least three times the demands required by the equipment. Experiments have shown that dimensional tolerances, according to the control charts, are adequate for the operation of the equipment.

\section{References}

[1] J. de Souza; C. A. Oliveira-Motta; T. G. Machado; A. Giacomin and H. M. A. Arabi. Analysis of Metallic Waste from Laser Cutting for Utilization in Parts Manufactured by Conventional Powder Metallurgy. International Journal of Research in Engineering and Science (IJRES). Vol.4 Issue 11 - November, 2016. p.01-05.

[2] J. de Souza; A. P. Borba; C. A. Oliveira-Motta; V. Martins and L. Schaeffer. Projeto de fabricação de face cilíndrica estacionária para biorreatores anaeróbios. Revista Liberato, Novo Hamburgo, v. 13, n. 19, p. 01-76, jan./jun. 2012.

[3] J. de Souza; C. A. Oliveira-Motta; and L. Schaeffer. Utilización de Ceniza Volante Aleada al Material Compuesto Hierro-CobreGrafito mediante un Proceso de Pulvimetalurgia. Información Tecnológica. Vol. 25(5), 21-26 (2014).

[4] J.S. Barboza, Caracterização de compósitos magnéticos macios desenvolvidos através da metalurgia do pó aplicados a núcleos de máquinas elétricas. Master's thesis. PPGE3M: UFRGS, 2009.

[5] A.C. Averú, L.V. Biehl, J.L.B. Medeiros and J. de Souza. Comparative Study of the Diffusibility of a Nickel Alloy composed by Ni-Cr-Fe. International Journal of Engineering Research and Technology (IJERT) Volume. 5, Issue. 12 - December, 2016.

[6] P. Pauletti, Construção e análise do desempenho de um motor de indução trifásico com núcleo produzido via metalurgia do pó. Master's thesis. PPGE3M: UFRGS, 2012.

[7] R. M. German. Coarsening in Sintering: Grain Shape Distribution, Grain Size Distribution, and Grain Growth Kinetics in SolidPore Systems. Critical Reviews in Solid State and Material Sciences 35(4):263-305, November 2010.

[8] M. P. Groover. Fundamentals of Modern Manufacturing: Materials, Processes, and Systems. $4^{\circ}$ ed. John Wiley \& Sons. 2010.

[9] C.A. Ferreira, Desenvolvimento de núcleos para transformadores monofásicos de baixa potência pela metalurgia do pó. Master's thesis. PPGE3M: UFRGS, 2011.

[10] D.C. Montgomery, Introdução ao controle estatístico de qualidade. $4^{\text {a }}$ Ed. 513p. Rio de Janeiro, 2004.

[11] J. Caburon, Aplicação do controle estatístico de processo em uma indústria do setor metal-mecânico: um estudo de caso. Artigo. XIII SIMPEP - Bauru, SP, Brasil, November 2006.

[12] M. Behbahani, A. Saghaee and R. Noorossana, A case-based reasoning system development for statistical process control: Case representation and retrieval. Computers \& Industrial Engineering, pp. 1107-1117. 2012. 